\title{
Vertical distribution of phosphorus concentrations, phosphatase activity and further soil chemical properties in salt-affected Mollic Gleysols in Poland
}

\author{
Joanna Lemanowicz $^{1} \cdot$ Magdalena Krzyżaniak $^{2}$
}

Received: 20 August 2014/ Accepted: 10 March 2015/Published online: 21 March 2015

(c) The Author(s) 2015. This article is published with open access at Springerlink.com

\begin{abstract}
The paper demonstrates distribution of the content of total and available phosphorus and activity of the alkaline and acid phosphatase against the selected properties of salt-affected Mollic Gleysols. In the adequately prepared soil, the following were determined: $\mathrm{pH}$, total organic carbon, the exchangeable cations $(\mathrm{Ca}$, $\mathrm{Mg}, \mathrm{Na}, \mathrm{K})$, salinity, the content of phosphorus, the activity of phosphomonoesterases. The distribution of the elements in the soil profiles was described with the value of the Distribution Index. To evaluate the availability of phosphorus, the Index of Mobility was used. The content of phosphorus varies, and it depends on physicochemical soil properties. Both the content of phosphorus available to plants and the activity of phosphatases in the profiles showed a high variation that depends both on the sampling date and on the depth. The lowest content of phosphorus was found in the profiles sampled in spring, during an intensive plant growth, while the greatest content was received in soil profiles sampled in summer. The research showed also a high variation in the time of the activity of phosphatases as well as their changes depending on the soil parameters, which was confirmed by the recorded values of the correlations between the activity of alkaline and acid phosphomonoesterases and the content of carbon,
\end{abstract}

Joanna Lemanowicz

j109@interia.pl

1 Sub-Department of Biochemistry, Faculty of Agriculture and Biotechnology, University of Science and Technology, 85-029 Bydgoszcz, Bernardyńska 6 St, Bydgoszcz, Poland

2 Department of Ecoengineering and Environment Physicochemistry, Faculty of Civil and Environmental Engineering and Architecture, University of Science and Technology, 85-789 Bydgoszcz, Sucha 9 St, Bydgoszcz, Poland respectively, $\quad(r=0.47, \quad P<0.05) \quad$ and $\quad(r=0.62$, $P<0.05)$ as well as available phosphorus $(\mathrm{r}=0.32$, $P<0.05)$ and $(r=0.38, P<0.05)$. A many-year seasonal salinity of soil did not decrease the activity of the phosphomonoesterases since it was mostly connected with the natural content of organic carbon.

Keywords Salt-affected soils (SAS) - Alkaline cations · Enzymes · Phosphorus · Phosphomonoesterases

\section{Introduction}

Phosphorus is one of the basic nutrients for plants (Condron et al. 2005); however, at the same time its excess in soil is responsible, e.g., for water eutrophication. Human activities can affect the biogeochemical cycling of phosphorus (Xue et al. 2013). The characteristic of phosphorus is its low availability due to slow diffusion and high fixation in soils (Shen et al. 2011). The phosphorus deficiency is a well-known nutrient constraint on salt-affected soils. Phosphorus occurs in organic and mineral bonds, and the content varies depending on the physicochemical soil properties (Turner et al. 2007; Lemanowicz et al. 2014). One of the indices of changes in the content of phosphorus in soil can be the measurement of the activity of soil phosphatases, especially phosphomonoesterases that take part in the process of mineralization of organic phosphorus (Nannipieri et al. 2011; Oprica et al. 2011; Orczewska et al. 2012). The measurement of activity of phosphomonoesterases points to the qualitative and quantitative changes in phosphorus in soil, as well as next to other enzymes, which is a good indicator of the soil pollution (Nowak et al. 2006; Rejsek et al. 2012; Krzyżaniak and Lemanowicz 2013). The activity of alkaline and acid 
phosphatases is also affected by soil carbon, nitrogen and organic matter content, and thus it can be used as an indicator for soil fertility (Dodor and Tabatabai 2003; Nannipieri et al. 2011).

Land degradation by salinization and sodication is a significant environmental problem (Lixia Wang et al. 2015). Salinity is the important environmental stress factor that affects the plant growth and nutrition of plant (Moghaddas et al. 2013). Solute salts accumulation can be due to a variety of natural and anthropogenic factors operating at a range of temporal and spatial scales (Wu et al. 2014). The occurrence of salt-affected soils (SAS) in Poland is connected with the impact of different natural and anthropogenic factors, of which the climate is relatively least important. In spite of some similarity to typical solonchaks and more rarely to solonetzes, these soils have very specific properties (Hulisz and Piernik 2013). Very often those are preliminarily other soil types exposed to a seasonal or continuous effect of various sources of salinity (Hulisz et al. 2010). Those are, for example, marine waters (Baltic coastal zone), waters in contact with Zechstein salt deposits (Central and NW Poland), waters in contact with Miocene salt deposits (Carpathian Depression, Nida Basin), soda industry wastes and brines (Central Poland), mine waters and mine-waste dumps (Upper and Lower Silesia). A specific factor that occurs in various regions of Poland and Europe is graduation towers. A constant supply of a large amount of cations and anions from the structures can, as a result, lead to permanent changes in the chemical properties of soils, making direct surroundings of the graduation towers. In fact, aerosol production is a natural process deriving from the interaction of wind stress graduation towers.

The primary objectives of present study were to determine distribution of the content of total and available phosphorus and the activities of alkaline and acid phosphatase of saltaffected Mollic Gleysols and to determine seasonal changes of the content phosphorus and the activity of phosphomonoesterase against its selected chemical properties.

\section{Materials and methods}

\section{Study area}

The research area is made up of an almost 60 ha of the Health Resort Park in Inowrocław, located in the $\mathrm{Ku}$ jawsko-Pomorskie Province, the Inowrocław county, the commune of Inowrocław (Central Poland). The location of the Health Resort Park in Inowrocław is determined by the latitude $\left(52^{\circ} 78^{\prime} \mathrm{N}\right)$ and longitude $\left(18^{\circ} 24^{\prime} \mathrm{E}\right)$, with the lowland climate of moderate altitudes (Krzyżaniak and Lemanowicz 2013). It is one of the driest regions, with the precipitation not exceeding $480 \mathrm{~mm}$, with an average temperature in May $12.3^{\circ} \mathrm{C}$, in August $19.4^{\circ} \mathrm{C}$, in November $3.8^{\circ} \mathrm{C}$ and prevailing winds from the western direction. The vegetation period takes on average 216 days per year.

Fig. 1 Location of soil profiles

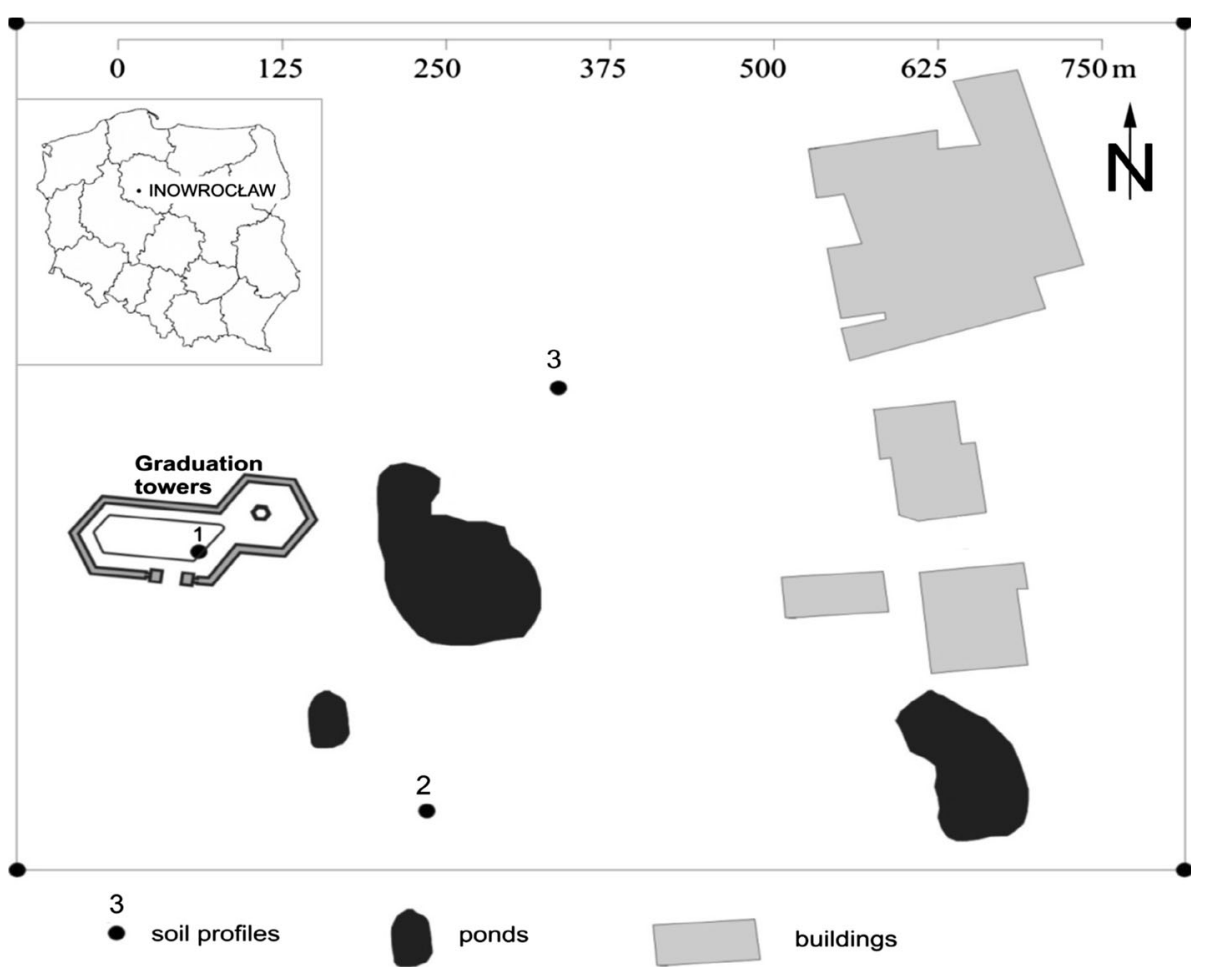


The soils in the research area have been classified based on the physicochemical properties, the grain-size composition and the profile structure as Mollic Gleysols (WRB 2006). The paper describes three profiles of salt-affected Mollic Gleysols (Fig. 1). Both in surface horizons and in the transition horizon of the profiles discussed, the sand fraction dominated (51-83\%), while the clay fraction demonstrated the tendency to the accumulation at various depths, in profile 1 in the surface horizon (19\%), and in profiles 2 and 3 in the transition horizon and the parent material (11-23 \%) (Krzyżaniak-Sitarz 2008).

\section{Soil analysis}

Soils were sampled by major genetic horizons using hand tools. Horizons were identified and recorded, along with horizon range and profile depth. Soils were passed through a 2-mm sieve to remove coarse soil including stones and root fragments. Prior to enzyme activity analysis, soil samples were thawed at $4{ }^{\circ} \mathrm{C}$ until soil enzymatic analysis was performed within 2 weeks of sampling, and soil moisture was determined after drying at $105{ }^{\circ} \mathrm{C}$ for $48 \mathrm{~h}$. A subset was air-dried in the laboratory and stored in closed polyethylene bags for physicochemical analysis. In the adequately prepared material, the following were determined: $\mathrm{pH}$ in $1 \mathrm{M} \mathrm{KCl}$ measured potentiometrically (Soil Survey LaboratoryStaff 1996), total organic carbon (TOC) with the TOC analyser Primacs provided by Scalar, the exchangeable cations of $\mathrm{Ca}, \mathrm{Mg}, \mathrm{Na}, \mathrm{K}$ in the extract of $1 \mathrm{M} \mathrm{NH} \mathrm{NCl}_{4}$ with $\mathrm{pH} 8.2$ using the atomic absorption spectrometry and emission spectrometry applying the spectrophotometer Philips PU 9100 (PN-ISO 11260 2011), salinity with the conductometric method (EC) (Reeuwijk 2002 ), and the content of total phosphorus ( $\mathrm{P}_{\text {TOT }}$ ) as described by Mehta et al. (1954), by treating soil with concentrated $\mathrm{HCl}$ and then with $0.5 \mathrm{M} \mathrm{NaOH}$. After mixing, the extracts were mineralized with a respective mixture of concentrated acids: nitric acid (V), perchloric acid (VII) and sulphuric acid (VI) at the ratio of 10:1:4. After mineralization, the optical density was assayed at $660 \mathrm{~nm}$ using Spectrophotometer Marcel Pro. The content of available phosphorus $\left(\mathrm{P}_{\mathrm{E}-\mathrm{R}}\right)$ was determined with the Egner-Riehm method-DL (PN-R-04023 1996), which involves the spectrophotometric measurement of the intensity of the colour of phosphorus-molybdenum blueproduced by orthophosphoric ions with molybdenum ions in the acid environment in the presence of $\mathrm{SnCl}_{2}$.

The activity of selected enzymes representing the class of hydrolases: alkaline phosphatase [E.C. 3.1.3.1] (AlP) and acid phosphatase [E.C. 3.1.3.2] (AcP) with the method of Tabtabai and Bremner (1969), based on the colorimetric determination of freed substrate $p$-Nitrophenylphosphate $(\mathrm{pNP})$ at $400 \mathrm{~nm}$. after the incubation of soil with of MUB
(Modified Universal Buffer) at pH 6.5 for acid phosphatase and $\mathrm{pH} 11$ for alkaline phosphatase samples for $1 \mathrm{~h}$ at the temperature of $37^{\circ} \mathrm{C}$ was determined.

\section{Statistical analysis}

Based on the present results of the activity of alkaline and acid phosphatases, the enzymatic index of soil $\mathrm{pH}$ (AlP/ AcP) was calculated (Dick et al. 2000).

All the assays were performed in three steps; the paper presents the arithmetic means of the results. The distribution of the elements in the soil profiles was described with the value of the distribution index (DI), calculated adequately (Kobierski and Dąbkowska-Naskręt 2012):

Distribution index (DI)

$$
=\frac{\text { the content of the element in the solum horizon }}{\text { content of the element in the parent material, }}
$$

where DI $<1$ stands for a lack of anthropogenic impact, $1 \leq \mathrm{DI} \leq 3$ stands for moderate accumulation, $3 \leq \mathrm{DI} \leq 6$ stands for a considerable accumulation, DI $>6$ stands for very high accumulation. To evaluate the availability of phosphorus, the Index of Mobility (IM) which expresses \% share of available phosphorus $\left(\mathrm{P}_{\mathrm{E}-\mathrm{R}}\right)$ in its total content was used. Based on the results, the index of changes in the content of the total organic carbon and phosphorus and the activity of phosphatases in time was calculated (Time index TI spring-autumn):

Time index $(\mathrm{TI})=\frac{\text { the content of the element in spring }}{\text { the content of the element in autumn, }}$

Besides, the results of the analyses were exposed to the analysis of simple correlation $(P<0.05)$ that determined the degree of the dependence between respective features. The analysis of the correlation was made using 'Statistica for Windows Pl' software (Poland).

\section{Results and discussion}

The organic matter and the concentration of respective cations in the diagnostic horizons of soils are affected by the content of organic carbon which, in the profiles discussed, ranges from 0.91 to $30.55 \mathrm{~g} \mathrm{ka}^{-1}$ (Table 1). The analysis of the TOC as well as DI content confirmed the accumulation of organic carbon mostly in the humus layer in all the profiles, irrespective of the season. The DI value in most horizons fell within the range of $3 \leq \mathrm{DI} \leq 6$ (Table 4), and so it stands for a considerable accumulation.

A constant inflow of alkaline cations in nature is reflected in the reaction and electrolytic conductivity of soils. Profile 1, due to a direct neighbourhood of the graduation 
Table 1 Content of total organic carbon (TOC), electrical conductivity and $\mathrm{pH} \mathrm{KCl}$

\begin{tabular}{|c|c|c|c|c|c|c|c|c|c|c|}
\hline \multirow[t]{2}{*}{ Depth $(\mathrm{cm})$} & \multirow[t]{2}{*}{ Horizon } & \multicolumn{3}{|c|}{ TOC $\left(\mathrm{g} \mathrm{ka}^{-1}\right)$} & \multicolumn{3}{|c|}{$\mathrm{EC}\left(\mathrm{dS} \mathrm{m}{ }^{-1}\right)$} & \multicolumn{3}{|c|}{$\mathrm{pH} \mathrm{KCl}$} \\
\hline & & Spring & Summer & Autumn & Spring & Summer & Autumn & Spring & Summer & Autumn \\
\hline \multicolumn{11}{|l|}{ Profile 1} \\
\hline $0-20$ & $\mathrm{Ak}$ & 9.49 & 24.18 & 9.75 & 1.48 & 1.77 & 1.43 & 7.63 & 7.02 & 7.44 \\
\hline $20-40$ & Ak2 & 12.74 & 30.55 & 17.55 & 1.70 & 1.79 & 1.18 & 7.64 & 7.15 & 7.22 \\
\hline $40-60$ & Ak3 & 8.32 & 21.45 & 13.39 & 2.12 & 1.96 & 1.64 & 7.66 & 7.15 & 7.49 \\
\hline $110-130$ & $\mathrm{AG}$ & 7.15 & 4.42 & 11.83 & 1.72 & 1.86 & 3.20 & 7.45 & 7.22 & 7.67 \\
\hline $130-150$ & Gk & 2.60 & 3.12 & 3.38 & 2.54 & 2.42 & 2.39 & 7.65 & 7.53 & 8.01 \\
\hline \multicolumn{11}{|l|}{ Profile 2} \\
\hline $0-20$ & A & 16.51 & 19.89 & 21.45 & 0.38 & 0.31 & 0.57 & 6.20 & 6.18 & 5.60 \\
\hline $20-40$ & $\mathrm{~A} 2$ & 11.83 & 10.92 & 13.45 & 0.31 & 0.25 & 0.32 & 6.40 & 6.21 & 6.15 \\
\hline $40-55$ & A3 & 9.10 & 10.40 & 13.13 & 0.30 & 0.26 & 0.35 & 6.41 & 6.23 & 6.20 \\
\hline $55-92$ & $\mathrm{AC}$ & 4.94 & 2.34 & 8.19 & 0.77 & 0.32 & 0.38 & 7.42 & 6.25 & 6.20 \\
\hline $92-150$ & $\mathrm{C}$ & 0.91 & 4.55 & 10.66 & 0.82 & 0.80 & 0.70 & 7.73 & 7.27 & 7.62 \\
\hline \multicolumn{11}{|l|}{ Profile 3} \\
\hline $0-20$ & A & 16.12 & 10.92 & 15.73 & 0.31 & 0.33 & 0.56 & 5.82 & 5.67 & 5.54 \\
\hline $20-40$ & $\mathrm{~A} 2$ & 10.14 & 15.60 & 8.97 & 0.20 & 0.25 & 0.38 & 6.01 & 5.62 & 5.86 \\
\hline $40-60$ & A3 & 6.89 & 15.47 & 7.80 & 0.17 & 0.22 & 0.31 & 6.03 & 5.81 & 5.95 \\
\hline $84-128$ & $\mathrm{AC}$ & 2.99 & 10.66 & 5.85 & 0.17 & 0.18 & 0.25 & 6.27 & 5.71 & 6.08 \\
\hline $128-150$ & $\mathrm{C}$ & 1.13 & 7.28 & 2.08 & 0.22 & 0.18 & 0.28 & 5.66 & 5.63 & 6.11 \\
\hline
\end{tabular}

tower, was clearly alkaline in nature irrespective of the sampling date or depth; unlike the reaction in the other two soil profiles. Both in profiles 2 and 3, the measurement of exchangeable acidity showed that we deal with slightly acid soils. In soil 3, the $\mathrm{pH}$ value in $1 \mathrm{M} \mathrm{KCl}$ ranges from 5.54 to 6.27 (Table 1). Those $\mathrm{pH}$ values lower than in the earlier described profiles are connected with the distance from the graduation tower and the occurrence of hydrogen cations in the sorption complex as well. In profile 2, despite the occurrence of $\mathrm{H}^{+}$ions in the complex, there was clearly visible an accumulation of alkaline cations in nature in the parent material horizon, which shows an increase in the reaction to alkaline. The reflection of physical and chemical processes that occur in soil, mostly the changes in the concentration of salts soluble in water, is the measurement of electrolytic conductivity (Corwin and Lesch 2005). The EC ranged from 0.17 to $3.20 \mathrm{dS} \mathrm{m}^{-1}$ and was highest at the profile I (1.18-3.20 dS m${ }^{-1}$ ) (Table 1). However, EC was low in most of the samples $\left(<2 \mathrm{dS} \mathrm{m}^{-1}\right)$ and only few higher values have $>2 \mathrm{dS} \mathrm{m}^{-1}$. The EC value showed an increase in that parameter with depth both in profiles 1 and 2. Profile 3 was an exception, here a decreasing tendency was observed. The results (Yu et al. 2014) showed that the salinity in topsoil was higher, indicating that the salt in subsoil moved up and accumulated in topsoil as a function of evaporation. The spatial distribution of soil salinity resulted from the comprehensive effects of anthropogenic activities and some natural factors. As compared to the parameters reported by other authors, higher EC values were found in all the three sampling periods in the samples located close to the source of salt (Strzelecka et al. 2011). One shall note that both the size of electrolytic conductivity and the measurement of $\mathrm{pH}$ in $1 \mathrm{M} \mathrm{KCl}$ were taken not in the saturated extract, but in the dilution soil-water $1: 5$, and so one can conclude that the results are lowered and do not fully reflect the real chemical properties of the soils (Table 2).

The analysis of the content of respective cations in the soil profiles under study showed that, irrespective of the sampling period, calcium ions dominated. In profiles 1 and $3, \mathrm{Ca}^{2+}$ in all the three sampling periods enriched the accumulation-humus horizon, while profile 2 showed the accumulation of calcium in the parent material horizon. Sodium came second in the composition of sorption complex. Profile 1 as well as the spring sampling of profile 3 showed the tendency to store sodium ions in the parent material horizon, whereas the soils of profile 2 as well as the soils from the summer and autumn sampling of profile 3 showed an enriched surface horizon. In this context, the general decrease of $\mathrm{EC}$ and $\mathrm{Na}$ towards the surface is probably related to the percolation of rain that "washes" and desalinizes the superficial horizons (Di Giuseppe et al. 2014). The concentration of magnesium ranged from 2.94 to $19.85 \mathrm{mmol}(+) \mathrm{kg}^{-1}$. Magnesium in all the horizons of the profiles under study assumed much lower values than it comes from literature data describing chemical parameters of Mollic Gleysols (Hulisz et al. 2010). There was also an inconsiderable share of $\mathrm{K}$-exchangeable in the sorption 
Table 2 Exchangeable cations in the surface samples

\begin{tabular}{|c|c|c|c|c|c|c|c|c|c|c|c|c|c|}
\hline \multirow{2}{*}{$\begin{array}{l}\text { Depth } \\
(\mathrm{cm})\end{array}$} & \multirow[t]{2}{*}{ Horizon } & \multicolumn{3}{|c|}{$\mathrm{Ca}^{2+}\left(\mathrm{mmol}(+) \mathrm{kg}^{-1}\right)$} & \multicolumn{3}{|c|}{$\operatorname{Mg}^{2+}\left(\operatorname{mmol}(+) \mathrm{kg}^{-1}\right)$} & \multicolumn{3}{|c|}{$\mathrm{K}^{+}\left(\mathrm{mmol}(+) \mathrm{kg}^{-1}\right)$} & \multicolumn{3}{|c|}{$\mathrm{Na}^{+}\left(\operatorname{mmol}(+) \mathrm{kg}^{-1}\right)$} \\
\hline & & Spring & Summer & Autumn & Spring & Summer & Autumn & Spring & Summer & Autumn & Spring & Summer & Autumn \\
\hline \multicolumn{14}{|l|}{ Profile 1} \\
\hline $0-20$ & Ak & 202.8 & 131.1 & 326.9 & 6.49 & 10.21 & 15.86 & 4.65 & 2.92 & 5.28 & 26.1 & 54.51 & 44.28 \\
\hline $20-40$ & Ak2 & 186.2 & 92.3 & 292.0 & 5.78 & 10.38 & 15.54 & 3.17 & 2.67 & 4.13 & 41.7 & 42.18 & 47.90 \\
\hline $40-60$ & Ak3 & 111.4 & 67.2 & 211.8 & 4.34 & 7.03 & 11.19 & 3.13 & 2.86 & 3.76 & 54.8 & 58.11 & 55.97 \\
\hline $110-130$ & $\mathrm{AG}$ & 73.5 & 38.5 & 162.7 & 2.94 & 4.92 & 6.68 & 2.98 & 2.41 & 3.25 & 60.2 & 64.78 & 93.31 \\
\hline $130-150$ & Gk & 72.5 & 102.5 & 330.4 & 3.14 & 4.99 & 5.86 & 3.15 & 2.48 & 3.45 & 66.5 & 65.30 & 88.56 \\
\hline \multicolumn{14}{|l|}{ Profile 2} \\
\hline $0-20$ & A & 139.5 & 92.2 & 159.5 & 6.65 & 11.27 & 12.74 & 6.08 & 4.79 & 3.40 & 18.3 & 30.15 & 25.85 \\
\hline $20-40$ & A2 & 205.4 & 85.7 & 172.9 & 5.88 & 11.14 & 11.12 & 3.42 & 3.48 & 2.99 & 11.1 & 21.89 & 23.78 \\
\hline $40-55$ & A3 & 349.3 & 100.1 & 172.3 & 6.99 & 13.62 & 15.21 & 3.00 & 3.03 & 3.17 & 14.6 & 21.92 & 26.88 \\
\hline $55-92$ & $\mathrm{AC}$ & 213.2 & 130.8 & 126.2 & 11.45 & 19.18 & 19.85 & 3.67 & 3.92 & 4.06 & 16.9 & 12.25 & 24.79 \\
\hline $92-150$ & C & 326.2 & 221.6 & 329.9 & 7.81 & 13.32 & 15.40 & 1.88 & 3.47 & 3.38 & 21.8 & 11.45 & 24.20 \\
\hline \multicolumn{14}{|l|}{ Profile 3} \\
\hline $0-20$ & A & 138.9 & 162.5 & 158.1 & 6.88 & 6.69 & 18.23 & 3.49 & 1.73 & 2.41 & 9.55 & 34.29 & 36.42 \\
\hline $20-40$ & $\mathrm{~A} 2$ & 125.7 & 333.5 & 107.4 & 3.60 & 5.72 & 8.26 & 1.96 & 1.90 & 2.54 & 6.26 & 31.75 & 23.82 \\
\hline $40-60$ & A3 & 87.8 & 204.2 & 125.9 & 3.02 & 6.20 & 11.22 & 2.13 & 2.06 & 2.47 & 8.51 & 13.87 & 30.50 \\
\hline $84-128$ & $\mathrm{AC}$ & 92.0 & 149.1 & 87.6 & 1.15 & 6.31 & 10.76 & 1.93 & 2.25 & 2.51 & 14.0 & 9.57 & 29.61 \\
\hline $128-150$ & $\mathrm{C}$ & 107.2 & 105.4 & 61.7 & 10.90 & 7.30 & 5.17 & 3.63 & 2.27 & 2.27 & 15.4 & 13.48 & 24.97 \\
\hline
\end{tabular}

complex of the soils analysed, ranging from 1.73 to $6.08 \mathrm{mmol}(+) \mathrm{kg}^{-1}$. It is difficult to determine finally the cause of such a low concentration of those two elements. The depletion of the complex with $\mathrm{Mg}^{2+}$ and $\mathrm{K}^{+}$can be due to an increased content of $\mathrm{Na}^{+}$in the soil solution and sorption complex, or to the elimination of magnesium, especially from the complex by calcium ions (Table 2).

The total content of phosphorus in soil determines only the level of their richness, and it does not show a possibility of the uptake of that element by the plants. The content of $\mathrm{P}_{\text {TOT }}$ ranged from 0.126 to $0.552 \mathrm{~g} \mathrm{ka}^{-1}$ (Table 3). In the profiles studied, the accumulation of that macronutrient was at a similar level. The lowest content of total phosphorus was found in the soil profiles sampled in summer. According (Ye et al. 2014), the content of total phosphorus in soils in spring was slightly lower than that in autumn, while available phosphorus levels in top soils in spring were obviously higher than those in autumn. The content of $\mathrm{P}_{\text {TOT }}$ was decreasing deep down the soil profiles. The content of total phosphorus in deeper horizons is mostly determined by the soil type and its soil-formation processes as well as the grain-size composition. The study by Ye et al. (2014) demonstrated that profile distributions of soil $\mathrm{P}$ did not show a significant variability and the content of the available phosphorus mainly accumulated in upper soils.

Defining the content of available forms in soils is important due to its availability to the plants, determined by the concentration of mobile forms in soil. The content of phosphorus available to plants $\left(\mathrm{P}_{\mathrm{E}-\mathrm{R}}\right)$ in the profiles varied (profile 1: $3.91-126.4 \mathrm{mg} \mathrm{ka}^{-1}$, profile 2: 2.82-70.23 mg ka ${ }^{-1}$, profile 3: 20.02-96.80 $\mathrm{mg} \mathrm{ka}^{-1}$ ) depending on the sapling date (Table 3 ). The lowest content of that nutrient was found in the profiles sampled in spring, during intensive plant growth, while the highest content in the soil profiles sampled in summer. Similar results were reported by Akmal et al. (2012), Imo et al. (2012). There was found a decrease in the content of $\mathrm{P}_{\mathrm{E}-\mathrm{R}}$ in deeper genetic horizons of profiles 2 and 3 where the greatest content was noted at the 0-20 cm depth. According to PN-R-04023, (1996), horizons $0-20 \mathrm{~cm}$ of the soil profiles show a very high content of available phosphorus marked with the EgnerRiehm method (DL), which classifies soil as class I. It is connected with a low mobility of that element, as compared to other nutrients (Wright 2009; Xu et al. 2012). In the soil of profile 1 , the greatest content of available phosphorus was recorded $20-40 \mathrm{~cm}$ deep (Table 3). According to Chhabra and Thakur (2000); Xiao et al. (2012), the high concentration of calcium in the soil results in the precipitation of insoluble calcium phosphate compounds for a short time, which may enhance the immobilization of $\mathrm{P}$ in soil solutions and decrease $\mathrm{P}$ availability; however, in Mollic Gleysols in Inowrocław exposed to seasonal salinity, a high content of ions in the soils responsible for salinity is balanced with a high content of carbon humus, 
Table 3 Content of total $\left(\mathrm{P}_{\mathrm{TOT}}\right)$ and available phosphorus $\left(\mathrm{P}_{\mathrm{E}-\mathrm{R}}\right)$ in soil and Index of Mobility (IM) for phosphorus

\begin{tabular}{|c|c|c|c|c|c|c|c|c|c|c|}
\hline \multirow[t]{2}{*}{ Depth (cm) } & \multirow[t]{2}{*}{ Horizon } & \multicolumn{3}{|c|}{$\mathrm{P}_{\text {TOT }}\left(\mathrm{g} \mathrm{kg}^{-1}\right)$} & \multicolumn{3}{|c|}{$\mathrm{P}_{\mathrm{E}-\mathrm{R}}\left(\mathrm{mg} \mathrm{kg}^{-1}\right)$} & \multicolumn{3}{|l|}{ IM (\%) } \\
\hline & & Spring & Summer & Autumn & Spring & Summer & Autumn & Spring & Summer & Autumn \\
\hline \multicolumn{11}{|l|}{ Profile 1} \\
\hline $0-20$ & Ak & 0.578 & 0.511 & 0.552 & 60.30 & 117.0 & 57.38 & 10.43 & 22.90 & 10.39 \\
\hline $20-40$ & Ak2 & 0.489 & 0.409 & 0.446 & 100.7 & 126.4 & 86.58 & 20.59 & 30.90 & 19.41 \\
\hline $40-60$ & Ak3 & 0.405 & 0.358 & 0.367 & 86.09 & 87.00 & 45.36 & 21.26 & 24.30 & 12.36 \\
\hline $110-130$ & $\mathrm{AG}$ & 0.328 & 0.311 & 0.319 & 61.95 & 62.19 & 11.60 & 18.89 & 20.00 & 3.636 \\
\hline $130-150$ & Gk & 0.167 & 0.145 & 0.152 & 19.95 & 40.46 & 3.91 & 11.95 & 27.90 & 2.572 \\
\hline \multicolumn{11}{|l|}{ Profile 2} \\
\hline $0-20$ & A & 0.501 & 0.481 & 0.493 & 49.15 & 70.23 & 69.63 & 9.810 & 14.60 & 14.12 \\
\hline $20-40$ & $\mathrm{~A} 2$ & 0.423 & 0.389 & 0.415 & 40.93 & 46.92 & 48.88 & 9.676 & 12.06 & 11.78 \\
\hline $40-55$ & A3 & 0.354 & 0.327 & 0.336 & 95.17 & 39.55 & 37.93 & 26.88 & 12.09 & 11.29 \\
\hline $55-92$ & $\mathrm{AC}$ & 0.211 & 0.188 & 0.198 & 55.82 & 38.18 & 30.05 & 26.45 & 20.31 & 15.18 \\
\hline $92-150$ & $\mathrm{C}$ & 0.154 & 0.127 & 0.134 & 2.82 & 20.02 & 5.646 & 1.831 & 15.76 & 4.213 \\
\hline \multicolumn{11}{|l|}{ Profile 3} \\
\hline $0-20$ & A & 0.521 & 0.418 & 0.493 & 70.32 & 96.80 & 81.79 & 13.50 & 63.68 & 16.59 \\
\hline $20-40$ & A2 & 0.399 & 0.341 & 0.357 & 40.93 & 84.37 & 70.83 & 10.26 & 24.74 & 19.84 \\
\hline $40-60$ & A3 & 0.364 & 0.294 & 0.304 & 77.40 & 95.17 & 67.65 & 21.26 & 32.37 & 22.25 \\
\hline $84-128$ & $\mathrm{AC}$ & 0.243 & 0.215 & 0.228 & 55.82 & 60.82 & 35.00 & 22.97 & 28.29 & 15.35 \\
\hline $128-150$ & $\mathrm{C}$ & 0.187 & 0.163 & 0.179 & 20.02 & 41.21 & 31.13 & 10.71 & 25.28 & 17.39 \\
\hline
\end{tabular}

directly affecting the fertility of the soil analysed (Krzyżaniak and Lemanowicz 2013).

The index of mobility (IM) evaluating the availability of phosphorus to plants was highest in the soil of profile 3 in all the research months (10.71-63.68\%), whereas the lowest in the horizons of profile 2 (1.831-26.88\%). There were also found seasonal changes in the IM value, which were highest in the soil profiles sampled in summer (Table 3). Available phosphorus can be directly absorbed by plants, which mainly derives from the conversion of total phosphorus. Study Xiao et al. (2012) demonstrated that higher IM ratios in soils could promote plant growth. In this study, the index IM for the soils was much higher than the threshold of available phosphorus load (2\%) for P effectiveness and bioavailability, indicating that soil $\mathrm{P}$ was sufficient for plant growth. However, the results reported by Ye et al. (2014) showed the IM for soils below the threshold of P load (2\%) for P bioavailability in spring and autumn, suggesting that the conversion rate from total phosphorus to available phosphorus was relatively low and the $\mathrm{P}_{\mathrm{E}-\mathrm{R}}$ supply for plant growth was deficient.

The distribution of nutrients in the soil profile depends on the content of organic matter, bioactivity and reaction as well as grain-size composition and anthropogenic factors (Jobbágy and Jacksonk 2001). The distribution of the total phosphorus content $\left(\mathrm{P}_{\text {TOT }}\right)$ in the profiles can be accounted for the effect of pedogenesis since, based on the DI value for the total content of phosphorus, there was identified its moderate accumulation (DI 1.27-3.79). There was identified a clear tendency to a considerable accumulation of $\mathrm{P}_{\text {TOT }}$ in horizons $0-20 \mathrm{~cm}$. The value of the distribution index (DI) calculated for available phosphorus $\left(\mathrm{P}_{\mathrm{E}-\mathrm{R}}\right)$ in the soil fell within the range of 1.12-22.14 (Table 4). In most genetic horizons of the profiles, there was found a moderate and considerable accumulation of that element. As for the soil profile 1 sampled in autumn, there was observed a clear tendency to the accumulation of $\mathrm{P}_{\mathrm{E}-\mathrm{R}}$ due to the anthropogenic effect (DI 11.60-22.14). The profile was situated in the closest vicinity of the graduation tower.

The activity of alkaline and acid phosphatase in soil profiles differed depending on the sampling date. The highest activity of alkaline (0.271-2.207 $\left.\mathrm{mM} \mathrm{pNP} \mathrm{kg}{ }^{-1} \mathrm{~h}^{-1}\right)$ and acid phosphomonoesterases (0.280-2.516 mM pNP $\mathrm{kg}^{-1} \mathrm{~h}^{-1}$ ) was reported in the soil sampled in spring (Table 5). Similar results were earlier recorded by Boerner et al. (2005); Sardans et al. (2006); Akmal et al. (2012), which is due to a lower content of available phosphorus in soil by intensive uptake by the root system of intensively growing plants. In response, soil microorganisms and plant roots release phosphatases to soil, thus catalysing the hydrolysis of organic phosphorus compounds to the mineral ones.

The highest activity of alkaline and acid phosphatase was recorded in the $0-20-\mathrm{cm}$ layer of the soil profiles sampled in spring (1.154-2.207 mM pNP $\mathrm{kg}^{-1} \mathrm{~h}^{-1}$ ) and autumn (1.014-1.553 mM pNP kg-1 $\mathrm{h}^{-1}$ ), while in summer in the 20- to 40-cm layer (0.647-1.283 mM pNP kg $\mathrm{kg}^{-1}$ ) 
Table 4 Distribution index (DI) of total organic carbon (TOC), total phosphorus $\left(\mathrm{P}_{\mathrm{TOT}}\right)$ and available phosphorus $\left(\mathrm{P}_{\mathrm{E}-\mathrm{R}}\right)$

\begin{tabular}{|c|c|c|c|c|c|c|c|c|c|c|}
\hline \multirow[t]{2}{*}{ Depth $(\mathrm{cm})$} & \multirow[t]{2}{*}{ Horizon } & \multicolumn{3}{|l|}{ TOC } & \multicolumn{3}{|l|}{$\mathrm{P}_{\mathrm{TOT}}$} & \multicolumn{3}{|l|}{$P_{E-R}$} \\
\hline & & Spring & Summer & Autumn & Spring & Summer & Autumn & Spring & Summer & Autumn \\
\hline \multicolumn{11}{|l|}{ Profile 1} \\
\hline $0-20$ & $\mathrm{Ak}$ & 3.65 & 7.75 & 2.88 & 3.46 & 3.52 & 3.63 & 3.02 & 2.89 & 14.68 \\
\hline $20-40$ & Ak2 & 4.90 & 9.79 & 5.19 & 2.93 & 2.82 & 2.93 & 5.05 & 3.12 & 22.14 \\
\hline $40-60$ & Ak3 & 3.20 & 6.88 & 3.96 & 2.43 & 2.47 & 2.41 & 4.32 & 2.15 & 11.60 \\
\hline $110-130$ & $\mathrm{AG}$ & 2.75 & 1.42 & 3.50 & 1.96 & 2.14 & 2.10 & 3.11 & 1.54 & 2.97 \\
\hline \multicolumn{11}{|l|}{ Profile 2} \\
\hline $0-20$ & A & 18.14 & 4.37 & 2.01 & 3.25 & 3.79 & 3.68 & 17.43 & 3.51 & 12.33 \\
\hline $20-40$ & $\mathrm{~A} 2$ & 13.00 & 2.40 & 1.26 & 2.75 & 3.06 & 3.10 & 14.51 & 2.34 & 8.66 \\
\hline $40-55$ & A3 & 10.00 & 2.29 & 1.23 & 2.30 & 2.57 & 2.51 & 33.75 & 1.98 & 6.72 \\
\hline $55-92$ & $\mathrm{AC}$ & 5.43 & 0.51 & 0.77 & 1.37 & 1.48 & 1.48 & 19.79 & 1.91 & 5.32 \\
\hline \multicolumn{11}{|l|}{ Profile 3} \\
\hline $0-20$ & A & 14.26 & 1.50 & 7.56 & 2.79 & 0.93 & 2.75 & 3.51 & 2.35 & 2.63 \\
\hline $20-40$ & $\mathrm{~A} 2$ & 8.97 & 2.14 & 4.31 & 2.13 & 2.09 & 1.99 & 2.04 & 2.05 & 2.28 \\
\hline $40-60$ & A3 & 6.10 & 2.13 & 3.75 & 1.95 & 1.80 & 1.70 & 3.87 & 2.31 & 2.17 \\
\hline $84-128$ & $\mathrm{AC}$ & 2.65 & 1.46 & 2.81 & 1.30 & 1.32 & 1.27 & 2.79 & 1.48 & 1.12 \\
\hline
\end{tabular}

Table 5 Activity of alkaline (AlP) and acid (AcP) phosphatases and ratio of alkaline to acid phosphatase AlP/AcP (Enzyme pH index) in soil

\begin{tabular}{|c|c|c|c|c|c|c|c|c|c|c|}
\hline \multirow[t]{2}{*}{ Depht $(\mathrm{cm})$} & \multirow[t]{2}{*}{ Horizon } & \multicolumn{3}{|c|}{ Alkaline phosphatase $\left(\mathrm{mM} \mathrm{pNP} \mathrm{kg}{ }^{-1} \mathrm{~h}^{-1}\right)$} & \multicolumn{3}{|c|}{ Acid phosphatase $\left(\mathrm{mM} \mathrm{pNP} \mathrm{kg}{ }^{-1} \mathrm{~h}^{-1}\right)$} & \multicolumn{3}{|c|}{ 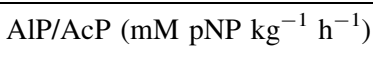 } \\
\hline & & Spring & Summer & Autumn & Spring & Summer & Autumn & Spring & Summer & Autumn \\
\hline \multicolumn{11}{|l|}{ Profile 1} \\
\hline $0-20$ & $\mathrm{Ak}$ & 1.154 & 0.816 & 1.066 & 1.510 & 1.632 & 1.316 & 0.78 & 0.50 & 0.81 \\
\hline $20-40$ & Ak2 & 1.021 & 0.834 & 0.888 & 1.118 & 1.883 & 2.024 & 0.91 & 0.44 & 0.44 \\
\hline $40-60$ & Ak3 & 0.855 & 0.719 & 0.632 & 0.949 & 0.823 & 1.068 & 0.90 & 0.87 & 0.59 \\
\hline $110-130$ & $\mathrm{AG}$ & 0.406 & 0.377 & 0.382 & 0.773 & 0.649 & 0.685 & 0.53 & 0.58 & 0.56 \\
\hline $130-150$ & Gk & 0.271 & 0.356 & 0.134 & 0.661 & 0.543 & 0.219 & 0.41 & 0.66 & 0.61 \\
\hline \multicolumn{11}{|l|}{ Profile 2} \\
\hline $0-20$ & A & 2.207 & 0.819 & 1.553 & 2.365 & 2.516 & 2.818 & 0.93 & 0.33 & 0.55 \\
\hline $20-40$ & A2 & 1.812 & 1.283 & 1.395 & 2.171 & 3.167 & 2.020 & 0.83 & 0.41 & 0.69 \\
\hline $40-55$ & A3 & 1.441 & 0.744 & 1.204 & 1.226 & 1.988 & 0.841 & 1.18 & 0.37 & 1.43 \\
\hline $55-92$ & $\mathrm{AC}$ & 1.057 & 0.439 & 0.722 & 0.859 & 1.200 & 0.755 & 1.23 & 0.37 & 0.96 \\
\hline $92-150$ & $\mathrm{C}$ & 0.316 & 0.183 & 0.203 & 0.280 & 0.443 & 0.330 & 1.13 & 0.41 & 0.62 \\
\hline \multicolumn{11}{|l|}{ Profile 3} \\
\hline $0-20$ & A & 1.484 & 0.568 & 1.014 & 2.045 & 1.402 & 1.168 & 0.73 & 0.41 & 0.87 \\
\hline $20-40$ & A2 & 1.316 & 0.647 & 0.863 & 1.675 & 1.229 & 1.078 & 0.79 & 0.53 & 0.80 \\
\hline $40-60$ & A3 & 0.683 & 0.456 & 0.604 & 0.776 & 0.999 & 0.956 & 0.88 & 0.46 & 0.63 \\
\hline $84-128$ & $\mathrm{AC}$ & 0.577 & 0.280 & 0.320 & 0.748 & 0.709 & 0.791 & 0.77 & 0.39 & 0.40 \\
\hline $128-150$ & $\mathrm{C}$ & 0.302 & 0.575 & 0.193 & 0.464 & 0.383 & 0.291 & 0.65 & 1.50 & 0.66 \\
\hline
\end{tabular}

(Table 5). The decreasing activity of enzymes deep down the soil profile is connected with the spatial distribution of humus and soil microorganisms together with a decreasing amount of carbon substrates available to microorganisms and enzymes. In summer, the inhibition of phosphatase in the surface layer can result from the exposure of top horizons to longer drying.
With the alkaline and acid phosphatase activity results, there was calculated the Enzymatic Index of Soil pH (AlP/ AcP) (Dick et al. 2000). Those authors show that when the value of the ratio AlP/AcP is higher than 0.50 , one can refer to neutral or alkaline soil reaction. The value of AlP/AcP of the soil profiles investigated falls within the range 0.33-1.50. In most cases, the values exceed 0.50 , which in the case of the 
Table 6 Factor of changes in the content of total organic carbon (TOC), total phosphorus $\left(\mathrm{P}_{\mathrm{TOT}}\right)$ and available phosphorus $\left(\mathrm{P}_{\mathrm{E}-\mathrm{R}}\right)$, and the activity of alkaline (AlP) and acid (AcP) phosphatase in time (TI)

\begin{tabular}{lllllll}
\hline Depth $(\mathrm{cm})$ & Horizon & TOC & P $_{\text {TOT }}$ & $\mathrm{P}_{\mathrm{E}-\mathrm{R}}$ & AlP & AcP \\
\hline Profile 1 & & & & & & \\
$0-20$ & Ak & 0.97 & 1.05 & 10.5 & 1.08 & 1.15 \\
$20-40$ & Ak2 & 0.73 & 1.10 & 1.16 & 1.15 & 0.55 \\
$40-60$ & Ak3 & 0.62 & 1.10 & 1.90 & 1.35 & 0.89 \\
$110-130$ & AG & 0.60 & 1.03 & 5.34 & 1.06 & 1.13 \\
130-150 & Gk & 0.77 & 1.10 & 5.10 & 2.02 & 3.02 \\
Profile 2 & & & & & & \\
$0-20$ & A & 0.77 & 1.02 & 0.71 & 1.42 & 0.84 \\
$20-40$ & A2 & 0.88 & 1.02 & 0.84 & 1.30 & 1.07 \\
$40-55$ & A3 & 0.69 & 1.02 & 2.51 & 1.20 & 1.46 \\
$55-92$ & AC & 0.60 & 1.07 & 1.86 & 1.46 & 1.14 \\
$92-150$ & C & 0.08 & 1.15 & 0.50 & 1.56 & 0.85 \\
Profile 3 & & & & & & \\
$0-20$ & A & 1.02 & 1.06 & 0.86 & 1.46 & 1.75 \\
$20-40$ & A2 & 1.13 & 1.12 & 0.58 & 1.52 & 1.55 \\
$40-60$ & A3 & 0.88 & 1.20 & 1.14 & 1.13 & 0.81 \\
$84-128$ & AC & 0.51 & 1.07 & 1.59 & 1.80 & 0.95 \\
$128-150$ & C & 0.54 & 1.04 & 0.64 & 1.56 & 1.59 \\
\hline
\end{tabular}

soil analysed was confirmed with the potentiometer method of $\mathrm{pH}_{\mathrm{KCl}}$ measurement, which is connected with the fact that phosphomonoesterases are the enzymes that are one of the most sensitive to $\mathrm{pH}$ changes (Dick et al. 2000; Dodor and Tabatabai 2003; Krzyżaniak and Lemanowicz 2013; Bartkowiak and Lemanowicz 2014).

The time index (TI) shows changes in the content of nutrients as well as the activity of phosphatases in soil from spring to autumn (Table 6). The content of the total phosphorus in soil from spring to autumn decreased (TI $>1$ ). The content of available phosphorus in soil profile 1 also decreased, especially in the 0 - to 20 -cm horizon $(\mathrm{TI}=10.5)$. In the $0-$ to $20-\mathrm{cm}$ and $20-$ to $40-\mathrm{cm}$ horizons of profiles 2 and 3, the content of $\mathrm{P}_{\mathrm{E}-\mathrm{R}}$ increased during research $(\mathrm{TI}<1)$. The profiles were much distant from the graduation towers, as compared to profile 1 . The activity of alkaline phosphatase from spring to autumn decreased (TI > 1), especially in the soil of profile 3 (TI 1.13-1.80).

With the analysis of correlation, there was reported a considerable dependence between the content of organic carbon and total phosphorus $(r=0.67, P<0.05)$ and available phosphorus in soil $(r=0.65, \quad P<0.05)$ (Table 7). The content of total phosphorus in profiles soil was generally dependent on the spatial heterogeneity of soil organic matter (Sun et al. 2013). Organic matter might have increased the solubility of phosphate in soils. The organic anions compete with phosphate ions for the
Table 7 Correlation coefficients significant at $P<0.05(n=90)$

\begin{tabular}{llllllll}
\hline Variable & $\mathrm{C}_{\text {org }}$ & $\mathrm{P}_{\text {TOT }}$ & $\mathrm{P}_{\mathrm{E}-\mathrm{R}}$ & $\mathrm{AlP}$ & $\mathrm{AcP}$ & $\mathrm{K}^{+}$ & $\mathrm{Na}^{+}$ \\
\hline $\mathrm{C}_{\text {org }}$ & - & 0.67 & 0.65 & 0.47 & 0.62 & $\mathrm{~ns}$ & $\mathrm{~ns}$ \\
$\mathrm{P}_{\text {TOT }}$ & & - & 0.63 & 0.72 & 0.72 & 0.35 & $\mathrm{~ns}$ \\
$\mathrm{P}_{\mathrm{E}-\mathrm{R}}$ & & & - & 0.32 & 0.38 & $\mathrm{~ns}$ & $\mathrm{~ns}$ \\
$\mathrm{AlP}$ & & & & - & 0.75 & 0.42 & -0.33 \\
$\mathrm{AcP}$ & & & & & - & 0.38 & $\mathrm{~ns}$ \\
$\mathrm{~K}^{+}$ & & & & & & - & $\mathrm{ns}$ \\
$\mathrm{Na}^{+}$ & & & & & & & - \\
\hline
\end{tabular}

ns non-significant

binding sites on the soil particles, or these anions may chelate with aluminium, iron and calcium, and thus decrease phosphate-precipitating power of these cations (Muralidhar et al. 2005).

It is common to observe a linear dependence between the activity of acid phosphatases and the amount of inorganic phosphorus forms released to the soil solution (Nannipieri et al. 2011), which is confirmed by statistical analysis showing a positive significant correlation between the content of $\mathrm{P}_{\mathrm{E}-\mathrm{R}}$ and AlP $(r=0.32, P<0.05)$ as well as AcP $(r=0.38, P<0.05)$. There was found a clear dependence between the content of organic carbon and the activity of alkaline $(r=0.47, P<0.05)$ and acid phosphomonoesterase $(r=0.62, P<0.05)$ in soil. Organic matter plays a key role as a precursor for enzyme synthesis, and in enzyme physical stabilization. According to Zhang et al. (2014), AlP activities were always correlated with organic matter $(\mathrm{OM})$ content significantly $(P<0.05)$. Higher indirect path coefficients were found in OM through $\mathrm{pH}$ and available phosphorus towards AlP activities, indicating that the effects of soil OM exerted indirectly. According to Laudicina et al. (2009); (Liu et al. 2013) in natural unreclaimed soil, the stimulation of microbial activity by organic inputs from native plants and/or the selection of salt-resistant microorganisms overcomes the osmotic stress induced by soluble salts. OM served as a precursor for enzyme synthesis (increasing soil microbial biomass, which is an enzyme source) and played a vital role in the physical stabilization of the enzyme. The positive effects of organic matter on AlP activities exerted indirectly available P. According to Rietz and Haynes (2003), the substantial AIP activities could persist even at high soil salinity and sodicity. Zahran (1997) noted that the production and activity of enzymes from the saline soil bacteria demonstrated salt requirements greater than those of the corresponding enzymes from non-saline bacteria.

There was not demonstrated a significant correlation between the salinity (EC) of Mollic Gleysols and the activity of alkaline and acid phosphatases and the content of phosphorus in soil. However, the results by Liu et al. 
(2013) showed that EC in the site increased and available $\mathrm{P}$ contents decreased.

There was demonstrated a positive significant low correlation between the content of $\mathrm{K}^{+}$, and the activity of alkaline $(r=0.42, \quad P<0.05)$ and acid phosphatases ( $r=0.38, P<0.05)$ in soil. The results reported by Banerjee et al. (2012) showed that the presence of ions $\mathrm{Na}^{+}, \mathrm{K}^{+}$, $\mathrm{Mg}^{2+}$, and $\mathrm{Ca}^{2+}$ increased the activity of phosphatases.

\section{Conclusions}

The soils under study are Mollic Gleysols exposed to a continuous inflow of alkalising factors, which is confirmed by the domination in the composition of ions of calcium and sodium as well as $\mathrm{pH}$ and EC values. The hot and prolonged spring and summer temperatures can favour salt deposition and accumulation in soil. The activity of alkaline and acid phosphatases in Mollic Gleysols varied depending on the sampling date. The highest activity of phosphomonoesterases was noted in the soil sampled in spring, and then in autumn, while in summer the activity was lowest, which was connected with the transformations of the total content of phosphorus and its available form.

A many-year seasonal salinity of Mollic Gleysols did not decrease the activity of the phosphomonoesterases since it was mostly connected with the natural content of carbon of organic compounds and with the factors affecting their salinity. The activity of alkaline and acid phosphatase as well as the content of phosphorus was highest in surface and sub-surface layers, and it was decreasing deep down the soil profiles. In most soil test pits, a clear effect of pedogenesis on the content of total and available phosphorus was identified, while in the profile located in the closest vicinity of the graduation tower the accumulation of available phosphorus due to the anthropogenic effect was found, which was confirmed by the results of the distribution index (DI).

Acknowledgments The authors would like to thank the Faculty of Agriculture and Biotechnology, University of Science and Technology in Bydgoszcz for their support for this research work.

Open Access This article is distributed under the terms of the Creative Commons Attribution License which permits any use, distribution, and reproduction in any medium, provided the original author(s) and the source are credited.

\section{References}

Akmal M, Altaf MS, Hayat R, Hassan FU, Islam M (2012) Temporal changes in soil urease, alkaline phosphatase and dehydrogenase activity in rainfed wheat field of Pakistan. J Anim Plant Sci 22(2):457-462
Banerjee A, Sanyal S, Sen S (2012) Soil phosphatase activity of agricultural land: A possible index of soil fertility. Agric Sci Res J 2(7):412-419

Bartkowiak A, Lemanowicz J (2014) Application of biochemical testes to evaluate the pollution of the Unislaw Basin soils with heavy metals. Int J Environ Res 8(1):93-100

Boerner REJ, Brinkman JA, Smith A (2005) Seasonal variations in enzyme activity and organic carbon in soil of a burned and unburned hardwood forest. Soil Biol Biochem 37:1419-1426

Chhabra R, Thakur NP (2000) Long-term study on phosphorus fertilization for rice-wheat cropping system in an alkali soils in the Indo-Gangetic plains. In: Abrol IP, Bronson KF, Duxbury $\mathrm{JM}$, Gupta RK (eds) Long-term soil fertility experiments in ricewheat cropping systems. (Rice-Wheat Consortium) Paper Series 6, Rice Wheat Consortium for the Indo-Gangetic Plains, New Delhi, pp 31-39

Condron LM, Turner BL, Cade-Menun BJ (2005) Chemistry and dynamics of soil organic phosphorus. In: Sims JT, Sharpley AN (eds) Phosphorus: agriculture and the environment. Agron Monogr 46. ASA, CSSA, and SSSA, Madison, WI, USA, pp 87-121

Corwin DL, Lesch SM (2005) Apparent soil electrical conductivity measurements in agriculture. Comput Electron Agric 46:1-3

Di Giuseppe D, Faccini B, Mastrocicco M, Colombani N, Coltorti M (2014) Reclamation influence and background geochemistry of neutral saline soils in the Po River Delta Plain (Northern Italy). Environ Earth Sci 72:2457-2473. doi:10.1007/s12665-0143154-4

Dick WA, Cheng L, Wang P (2000) Soil acid and alkaline phosphatase activity as $\mathrm{pH}$ adjustment indicators. Soil Biol Biochem 32:1915-1919

Dodor DE, Tabatabai MA (2003) Effect of crop rotation systems on phosphatases in soil. J Plant Nutr Soil Sci 166:7-13

Hulisz P, Piernik A (2013) Soils affected by soda industry in Inowrocław. In: Charzyński P, Hulisz P, Bednarek R (eds) Technogenic soils of Poland. Polish society of soil science, Toruń: 125-140 (2007) Selected aspects research of salt-affected soils in Poland. SOP, Toruń, 40

Hulisz P, Charzyński P, Giani L (2010) Application of the WRB classification to salt-affected soils in Poland and Germany. Polish J Soil Sci 43(1):81-92

Imo T, Latū F, Elisaia-Vaai A, Arakaki T, Sheikh MA (2012) Monitoring the impacts of red soil runoff along the Matafa'a Mangrove conservation area in Samoa. Int J Environ Sci Dev 3(5):446-449

Jobbágy EG, Jacksonk RB (2001) The distribution of soil nutrients with depth: global patterns and the imprint of plants. Biogeochemistry 53:51-77

Kobierski M, Dąbkowska-Naskręt H (2012) Local background concentration of heavy metals in various soil types formed from glacial till of the Inowrocławska Plain. J Elem 17(4):559-585

Krzyżaniak M, Lemanowicz J (2013) Enzymatic activity of the Kuyavia Mollic Gleysols (Poland) against their chemical properties. Plant Soil Environ 59(8):359-365

Krzyżaniak-Sitarz M (2008) Influence of anthropopressure on physicochemical properties of soils in the Spa Park in Inowroclaw. Ecol Tech 16:181-189

Laudicina VA, Hurtado MD, Badalucco L, Delgado A, Palazzolo E, Panno M (2009) Soil chemical and biochemical properties of a salt-marsh alluvial Spanish area after long-term reclamation. Biol Fertil Soils 45:691-700

Lemanowicz J, Siwik-Ziomek A, Koper J (2014) Effects of farmyard manure and nitrogen fertilizers on mobility of phosphorus and sulphur in wheat and activity of selected hydrolases in soil. Int Agrophys 28:49-55 
Liu C, Xu JM, Ding NF, Fu QL, Guo B, Lin YC, Li H, Li N (2013) The effect of long-term reclamation on enzyme activities and microbial community structure of saline soil at Shangyu, China. Environ Earth Sci 69:151-159

Mehta NC, Legg JO, Goring CA, Black CA (1954) Determination of organic phosphorus in soils. Soil Sci Soc Am Proc 44:443-449

Moghaddas NH, Namaghi HH, Ghorbani H, Dahrazma B (2013) The effects of agricultural practice and land-use on the distribution and origin of some potentially toxic metals in the soils of Golestan province, Iran. Environ Earth Sci 68(2):487-497. doi:10.1007/s12665-012-1753-5

Muralidhar M, Gupta BP, Jayanthi M (2005) Quantity -intensity relationship and fixation of phosphorus in soils from shrimp farming areas of coastal India. Indian J Fish 52(4):421-431

Nannipieri P, Giagnoni L, Landi L, Renella G (2011) Role of phosphatase enzymes in soil. In: Bunemann EK (ed) Phosphorus in action, soil biology. Springer-Verlag, Berlin Heidelberg, pp 215-243

Nowak J, Kąklewski K, Klódka D (2006) Influence of various concentrations of selenic acid (IV) on the activity of soil enzymes. Sci Total Environ 291:105-110

Oprica L, Olteanu Z, Dunca SI, Marius S, Zamfirache MM (2011) The tillage effect on the soil acid and alkaline phosphatase activity. Analele Stiintifice ale Universitatii „Alexandru Ioan Cuza", in: Sectiunea Geneticasi Biologie Moleculara 12:103-110

Orczewska A, Piotrowska A, Lemanowicz J (2012) Soil acid phosphomonoesterase activity and phosphorus forms in ancient and post-agricultural black alder [Alnus glutonosa (L.) Gaertn.] woodland. Acta Soc Bot Pol 81(2):81-86

PN-EN ISO 11260 (2011) Soil quality-determination of effective cation exchange capacity and base saturation level using barium chloride solution. Polish Standards Committee, Warszawa

PN-R-04023 (1996) Chemical and agricultural analysis-determination of the content available phosphorus in mineral soils. Polish Standards Committee, Warszawa

Rejsek K, Vranova V, Pavelka M, Formanek P (2012) Acid phosphomonoesterase (E.C. 3.1.3.2) location in soil. J Plant Nutr Soil Sci 175:196-211

Rietz DN, Haynes RJ (2003) Effects of irrigation-induced salinity and sodicity on soil microbial activity. Soil Biol Biochem 35:845-854

Sardans J, Penuelas J, Estiarte M (2006) Warming and drought alter soil phosphatase activity and soil $\mathrm{P}$ availability in a Mediterranean shrubland. Plant Soil 289:227-238

Shen J, Yuan L, Zhang J, Li H, Bai Z, Chen X, Zhang W, Zhang F (2011) Phosphorus dynamics: from soil to plant. Plant Physiol 156:997-1005

Soil Survey LaboratoryStaff (1996) Soil Survey Laboratory Methods Manual. Version 3.0. National Soil Surkey Center Soil Survey Investigations Raport no. 42. U.S. Department ofAgriculture, Lincoln, $\mathrm{Ne}$

Strzelecka S, Dąbrowski M, PiernikA Hulisz P (2011) Changes in soil properties and plant biomass under the influence of soda waste ponds in Inowrocław, Poland. Ecol Quest 14:69-71
Sun Z, Mou X, Tian H, Song H, Jiang H, Zhao J, Sun W, Sun W (2013) Phosphorus biological cycle in the different Suaeda salsa marshes of the Yellow River estuary, China. Environ Earth Sci 69:2595-2608. doi:10.1007/s12665-012-2081-5

Tabatabai MA, Bremner JM (1969) Use of $p$-nitrophenol phosphate for assay of soil phosphatase activity. Soil Biol Biochem 1:301-307

Turner BL, Richardson AE, Mullaney EJ (2007) Inositol phosphates: linking agriculture and the environment. CAB International, Wallingford, p 304

van Reeuwijk LP (2002) Procedures for soil analysis, 6th edn. ISRIC, FAO, Wageningen

Wang Lixia, Yan BaiXing, Zhu Lilu, Yang Ou (2015) The effect of reclamation on the distribution of heavy metals in saline-sodic soil of Songnen Plain, China. Environ Earth Sci 73:1083-1090. doi:10.1007/s12665-014-3464-6

World reference base for soil resources 2006 (2006) World soil resources reports No. 103. FAO, Rome

Wright AL (2009) Soil phosphorus stocks and distribution in chemical fractions for long-term sugarcane, pasture, turfgrass, and forest systems in Florida. Nutr Cycl Agroecosyst 83:223-231

Wu JH, Li PY, Qian H, Fang Y (2014) Assessment of soil salinization based on a low-cost method and its influencing factors in a semiarid agricultural area, northwest China. Environ Earth Sci 71(8):3465-3475. doi:10.1007/s12665-013-2736-x

Xiao R, Bai JH, Gao HF, Huang LB, Deng W (2012) Spatial distribution of phosphorus in marsh soils of a typical land/inland water ecotone along a hydrological gradient. Catena 98:96-103

Xu G, Shao HB, Sun JN, Chang SX (2012) Phosphorus fractions and profile distribution in newly formed wetland soils along a salinity gradient in the Yellow River Delta in China. J Plant Nutr Soil Sci 175:721-728

Xue QY, Dai PB, Sun DS, Sun CL, Qi LY, Ostermann A, He Y, Lin XY (2013) Effects of rainfall and manure application on phosphorus leaching in field lysimeters during fallow season. J Soils Sediments 13:1527-1537

Ye X, Bai J, Lu Q, Zhao Q, Wang J (2014) Spatial and seasonal distributions of soil phosphorus in a typical seasonal flooding wetland of the Yellow River Delta, China. Environ Earth Sci 71:4811-4820. doi:10.1007/s12665-013-2872-3

Yu JB, Li YZ, Han GX, Zhou D, Fu YQ, Guan B, Wang GM, Ning K, Wu HF, Wang JH (2014) The spatial distribution characteristics of soil salinity in coastal zone of the Yellow River Delta. Environ Earth Sci 72(2):589-599. doi:10.1007/s12665-0132980-0

Zahran HH (1997) Diversity, adaptation and activity of the bacterial flora in saline environments. Biol Fertil Soils 25:211-223

Zhang TB, Kang Y, Liu SH, Liu SP (2014) Alkaline phosphatase activity and its relationship to soil properties in a saline-sodic soil reclaimed by cropping wolfberry (Lycium barbarum L.) with drip irrigation. Paddy Water Environ 12:309-317 